\title{
CONTROLLING FICTIONS: METHODOLOGICAL PARADOXES AND POLITICAL DEAD ENDS OF THE NEW MELANESIAN ETHNOGRAPHY
}

\begin{abstract}
The paper contributes to the anthropological debate surrounding the methodology of the New Melanesian Ethnography and the model of the dividual personhood it is based on. The author introduces a disciplinary and historical context in which the theory was formulated and proposes an extended explication of the monograph The Gender of the Gift that is generally credited as the seminal work for the theoretical movement. Two points of critique are introduced and foregrounded in the ethnographic material from Papua New Guinea and Vanuatu: the limited heuristic potential of the dividual model and its ideological relativism that is fraught with dangerous political consequences for the disciplinary project of anthropology.
\end{abstract}

Keywords: New Melanesian Ethnography, dividual, Marilyn Strathern, Vanuatu, gender inequality.

\section{Introduction}

Anthropology is, by its very nature, an archipelago, not a continent. The discipline consists of a number of geographically and thematically delineated subfields, the practitioners within which rarely gain any traction beyond the domain in which they labor. Perhaps the only reliable path to academic stardom for an anthropologist lies through methodological innovation: to propose a new research procedure, analytical optics, or epistemological doctrine that can be appropriated by the occupants of other parts of the discipline's island group. The successful invention can propel the author to pan-anthropological or, with a substantial amount of luck, pan-social science fame. By this measure, Melanesian anthropology of the last three decades has hardly produced any superstars except for Marilyn Strathern and the particular brand of the New Melanesian Ethnography associated with her name.

The British Melanesianist did not only manage to become an adjective (see Street and Copeman 2014 for attempts at defining "Strathernian Analysis" and "Strathernian Anthropology") which is, according to Pierre Bourdieu, the highest distinction a theorist may aspire to, but was also explicitly credited as an inspiration and an influence by the scholars of note from distant anthropological quarters (Tsing 2015). Last but not least, Strathern's late-eighties writings set in train a dispute that remained central to Oceanic anthropology for more than twenty years and started showing some signs of waning only in mid-teens. The following paper is an admittedly late contribution to that smoldering theoretical controversy.
Although Strathern's input should not be caricatured to coining a single concept or idea, the majority of appropriations of her "methodology" among Oceanic anthropologists consist in making use of the model of radically transactional and decentered personhood unit she proposed for the New Guinea material and Melanesia in general in her 1988 monograph The Gender of the Gift, the "dividual." The dividual is defined by Strathern in explicit opposition to individual: the mode of personhood propagated and perpetuated by "the West" and various institutions of "Modernity." Individual is construed as an autonomous agent completely independent of the relationships that contributed to his or her formation and maturation; a unique source and author of his or her actions. Conversely, dividual is "frequently constructed as the plural and composite site of the relationships that produced" him (Strathern 1988, 13); he or she already contains a "social microcosm" within and envisions actions she brings about as the consequences of internalized relationships she earlier partook of. I will try to demonstrate that the dividual model is heuristically redundant and politically dangerous. It proposes a highly unintuitive and convoluted theoretical model for thinking about the processes that can be made graspable by means of more traditional and empirically-informed conceptual tools. More crucially, it obscures the systematic presence of rigid and all-pervasive practices of discrimination, privation, and violence in Melanesian societies and naturalizes them as an expression of the local ontologies. 


\section{Cultures without interpretation: the Melanesian conundrum}

The New Melanesian Ethnography (NME) is a late-twentieth-century attempt to crack the riddle that, in many ways, has haunted the anthropology of the region since its inception. Even though the birth of social anthropology as a discipline is associated with Oceania through the towering figure of Bronislaw Malinowski who famously conducted fieldwork off the shore of New Guinea, the first wave of systematic studies undertaken here in the midtwentieth century often left the researchers unable to make sense of the laws that governed the native societies scattered throughout the South Pacific.

The puzzlement was probably most pronounced in the case of Papua New Guinea (PNG) highlands which finally became open for ethnographic fieldwork in the decade following the end of World War II. However, when the first generation of anthropologists-Ronald and Catherine Berndt, D'Arcy Ryan, Reo Fortune among others - finally touched the ground, they discovered that the Africanist models they were raised on were extremely ill-suited for description of the reality they found in the field (Strathern 1992). Instead of a rigid prescriptive set of rules delineating the social structure and its modes of reproduction, the NewGuinean cultures met them with a fluid stream of intersecting categories that were strategically manipulated by the actors in order to achieve their particular ends. Thus the apparent stability of inheritance or kinship rules in some PNG societies were spectacularly undercut by the ease with which new members could have been "transformed" into kinsmen through ritual procedures or multi-tiered transactions of valuables. It took almost two decades to work out the conceptual apparatus for modelling the fundamentals of local sociality; the answer ultimately came from Marcel Mauss' theory of the gift exchange and the painstaking ethnographic labor of Melanesian anthropologists themselves. Yet, such questions as the functioning of gender across the varieties of PNG societies lingered.

The same tension manifested itself throughout the entire region of Melanesia. When Jean Guiart, a French anthropologist, came to investigate the turbulent social processes in Vanuatu (then New Hebrides) archipelago in nineteen-fifties, he concluded, no less, that "the terms of classical sociology" were inapplicable to the society of Tanna island where he conducted his fieldwork. The thicket of power claims, ritual statuses, and cross-cutting social "categories" (Guiart's "census" revealed that the majority of adult male population was entitled to some kind of authority position in terms of either ancestral magical rights or chiefly status) prompted him to admit:

A humbled spirit might condense the results of research by saying that we have discovered only flux, little more. In the most objective terms it appeared to us impossible to describe an ordered and rigorous social system. The scattering of authority appears as a local consequence, pushed nearly to absurdity, of a general tendency in the archipelago (Guiart 1956, cited in and translated from French by Lindstrom 1981, 27-8).

A decade earlier another French ethnographer, Maurice Leenhardt, who worked in the neighboring archipelago of New Caledonia, felt that the differences between the European and Melanesian cultures run even deeper and hypothesized that his Kanak respondents understood the very notion of person differently. According to him, for New Caledonians their

social reality is not in their body but in this empty place where they have their names and which corresponds to a relationship. ... But no name can cover the whole person. The Canaque [Caledonian] is obliged to have a different name for every domain which involves his person in various relationships and participations. In all this, he is unaware of himself; he is the empty space enclosed by the circle of [social interactions] (Leenhardt 1979 [1947] cited in Strathern 1988, 268).

Such a sharp us/them dichotomy naturally invites suspicions of complicity with colonial modes of thinking and discourse. Yet, Leenhardt can hardly be seen as an imperialist aficionado; he was extremely compassionate towards his native respondents, campaigned to alleviate their condition, and ultimately co-founded Société des Océanistes in Paris. Perhaps even more importantly, his quarter of century worth of ethnographic experience cannot be brushed off: something strange indeed seemed to be going on with people, things, and relationships between them in Melanesia.

An even remotely representative catalogue of the Melanesian social phenomena that seem to evade explanation in terms of standard Western concepts of personhood and sociality would, of course, take volumes. Instead, this section will conclude with a selection of three such instances voluntaristically borrowed from anthropological literature to bring some ethnographic detail into my discussion and to make the subsequent presentation of Marilyn Strathern's dividuality argument more persuasive. 
The first one comes from the Maring of PNG highlands and is reported by Edward LiPuma. The ethnographer claims that his Maring informants seem not to posit the existence of independent individual consciousness in explaining the actions of others in the context of everyday activities. Individual biographies are recalled as chains of exchanges and reciprocated or unreciprocated transactions. Thus, instead of referring to a person's psychological characteristics - i.e. that he or she is greedy, generous, cunning - locals present records of his or her actions - i.e. that he or she is known to participate in quarrels, to be a gambler, or an impressive gardener. This cognitive stance is not merely cultural but also linguistic:

Maring locate intention in the relationship between an action and its influence rather than in the "mind" of the agent. There is no means in Maring to speak about someone's intentions or judgments apart from what they do and other people's experience of those acts. There is no way to differentiate between the mental dimension of an act and the act itself; rather the action is understood to embody a hierarchy of intentions (LiPuma 1998, 65-6).

The second concerns the Sia Raga people of North Pentecost (Vanuatu) and was recorded by John Patrick Taylor. In the following excerpt Taylor offers a description of the rationale behind the ritual performed by tarabe (mother's brother) of the yet unborn child in order to ensure his or her place in the kinship hierarchy:

Immediately following the performance of tai simano [the washing of the belly of the pregnant woman, tarabe's sister, with coconut milk], the tarabe will disclose to the expectant mother the future of her unborn child - whether it will be a boy or girl, whether it will be a chief, and so on. This predestination is made possible by the cyclical nature of Sia Raga notions of personhood. The Sia Raga do not believe that each person is a unique individual, but rather a mixture of distinctive character traits and those acquired through their position as reembodied ancestors. By assessing the matrilineal pedigree of the child's parents, the place of birth (bwatun vanua), and the season during which the birth will take place, the child's tarabe, as a knowledgeable matrilineal leader, is able to ascertain the identity of the matrilineal ancestor about to be reborn (Taylor 2008, 122).

The third ethnographic example originates in PNG but takes place in a much more "modern" setting of Papua-New-Guinean penitentiary system.
In his study of life in Port Moresby prison, Adam Reed records the reaction of inmates to the news of the sentencing of a local man named Charles Bongapa Ombusu to death by a state court in February of 1995. The sentence was a sensation as far as death penalty was only reintroduced four years earlier and no action of the sort was performed since 1954, the colonial times. Inmates expressed a wide range of attitudes including solidarity with the man they perceived as their peer and raising questions about the necessity, appropriateness, and justification behind the state's right to take life. However, their reaction also involved articulations that throw in sharp relief the differences between Melanesian and Western understandings of sociality, reciprocity, and personal autonomy:

Max, a convict from Goilala and gang mate of Ombusu, told me that he felt sorry for his comrade. He warned that if the government did go ahead and execute him, Ombusu's gang mates would be forced to retaliate. They might attack the court witnesses who spoke against him, the sentencing judge, national politicians or civil servants. Max said that Ombusu's kin and language mates would feel the same way. [...] Papua New Guinea, [prisoners] explained was not like the countries of white people such as Australia and the United States of America. There, people lived independently or one-one, left their parents and kin as soon as they matured and married. [...] But in Papua New Guinea, they countered, people lived one-time, they couldn't forget the obligations they owed to others [...]. Prisoners insisted that State execution would be a disaster, involving the government in an open cycle of injury and revenge (Reed 2004, 169-70).

The last illustration is especially apt as far as in it the distinction between Western and Melanesian societies/persons is drawn by the representatives of the latter themselves, not by anthropologists. In any case, as should be evident by this point, the basic mechanics of social life and personal agency in the region seems to operate on the principles quite alien to the ones contemporary Western social ontology is assumed to be based on. So, the scene for the entrance of the New Melanesian Ethnography is set.

\section{The Gender of the Gift}

The late nineteen-eighties writings of Marilyn Strathern did not present the sole seminal contribution to the development of the theoretical movement subsequently christened the New Melanesian Ethnography. Lisette Josephides in her 1991 review article applied the label to four 
monographs published in 1987-1988: Fredrik Barth's Cosmologies in the making, Jadran Mimica's Intimations of infinity, James Weiner's The heart of the pearlshell, and Strathern's The gender of the gift (Josephides 1991). However, it was the latter volume that (arguably) was the most radical in its epistemology, received the biggest share of traction and critical comment, and later came to define NME to the extent of Strathern's notion of "dividual" becoming essentially synonymous with it.

The gender of the gift: problems with women and problems with society in Melanesia, to use its full title, was written on Papua-New-Guinean material. Strathern pursued a number of interconnected aims but her main task, as it gradually became apparent to the reader, was to construct the theory of agency and social structure for Melanesian societies that would have been written from the indigenous perspective, without a recourse to the established categories of Western sociological analysis. Strathern, of course, was aware that it is impossible to extricate oneself from one's generative concepts entirely. That is why she referred to the rigid dichotomy between Western and Melanesian societies her monograph consistently introduced as to the "controlled fiction" (Strathern 1988, 6). The implication being that the assumptions she made were of "pragmatic" quality and helped to shed light on otherwise obscured regularities and patterns of practice and thought. The epistemology of The gender of the gift was, in the spirit of its time, emphatically postmodern. Strathern claimed that anthropological discourse about Melanesian societies-including the one she was about to weave - was in no way privileged over the native modes of self-understanding and self-description. This is, obviously, a self-defeating stance for a theorist to take. More importantly, it is selfcontradictory. As Josephides poignantly observed in her review of The gender of the gift, "Nonetheless a privileged understanding does emerge, because (running counter to her disclaimers) Strathern's deconstructive method culminates in the construction of a theory of action whose persuasiveness depends on the generality with which it can be applied" (Josephides 1991, 146). The basics of this theory rested on a number of propositions, which I will attempt to explicate.

Perhaps the most significant achievement of the volume from the perspective of Melanesian anthropology (narrowly defined) was the creation of the framework within which the highlands and lowlands societies of PNG could be compared. On the surface the two appeared to be radically disjoined or even incommensurable. Typical highlands cultures were of the classical big-men type, revolved around the ceremonial exchanges and bridewealth marriages. The sociality of lowlanders, on the other hand, focused on initiation rituals and sister exchange (Hirsch 2014, 45). Instead of positing either one as an "evolutionary" development of the other, Strathern sought to demonstrate that both were based on the same underlying paradigm of agency.

She claimed that for all PNG societies gender provided the principal metaphor and cognitive frame for conceptualizing difference. "Male" or "female" identities were not as much stable biological classifications as ritual valences which could be acquired by men, women, sacred objects, supernatural beings, or other entities depending on the position in which they were supposed to act throughout the specific ceremony or procedure in question. Therefore, both initiation and the exchange of valuables were pictured as means for achieving the end of providing nurturance, internalizing and harnessing the procreative powers of both biological sexes that achieved maximum generative potential when they encompassed each other.

Consequently, the meaning of the term "gender" in Strathern's model expanded and transformed. It became applicable to "internal relations between parts of persons, as well as their externalization as relations between persons" (Strathern 1988, 185). Taking a step further, the author claimed that the pivotal gender relationship for Papua-NewGuineans (and, by extension, Melanesians) is not between male and female but between same-sex and cross-sex composites either within the same person or between different persons (or social entities such as clans): "same-sex relations and cross-sex relations [may be apprehended] as the gendered forms of persons who must appear as either singular or multiple in their composition. The one is a potential transformation of the other" (Strathern 1988, 185). This transformation or "activation" was the primary objective of both initiation ceremonies of the lowlands and exchange rituals of the highlands. Strathern saw the tangible embodiment of this logic in polyvalent ritual objects (that can be symbolically read as either breasts or phalluses) and androgynous supernatural figures that played crucial role in many PNG mythologies.

Another "controlled fiction" employed by The gender of the gift was a contrast between giftbased economies and commodity-based economies previously elaborated by Christopher Gregory's Gifts and commodities (Hirsch 2014, 44). Insofar as objects in the gift economies are never truly separated from their producers, the concept of 
"alienation" and "economic exploitation" in the Marxist sense of both terms were inapplicable. The work of the person that contributed to the creation/ nurturing of the item (a pig, a ceremonial mat, an axe, a grass skirt, a child etc.) is always visible in the finished product: "Persons simply do not have alienable items, that is, property, at their disposal; they can only dispose of items by enchaining themselves in relations with others" (Strathern $1988,161)$. Indeed, it is the connection to the activities and social selves of others that marks such objects as valuable and desirable. Strathern was ready to go even further and envision a radically different type of agent-act relationship than the one commonly presupposed by both terms: "What deceives us perhaps is the very fact that agents do not cause their own actions; they are not the authors of their own acts. They simply do them. Agency and cause are split" (Strathern 1988, 271). That is to say, according to The gender of the gift, in Melanesia the person that performs an action should not necessarily be considered its author. The intent and the immediate causal agency usually rest in different loci and the "source" can be always seen or deduced in the action (such as the transfer of wealth in ceremonial exchange) due to the gift-based nature of the local economies.

In the absence of alienation, erasure of the original producer, and systematic exclusion it is predictably impossible to talk about systematic discrimination:

being active and passive are relative and momentary positions; in so far as the relevant categories of actors are 'male' and 'female' then either sex may be held to be the cause of the other's acts; and the condition is evinced in the perpetual possibility of the one being vulnerable to the exploits of the other or able to encompass the other. The conclusion must be that these constructions do not entail relations of permanent domination" (Strathern 1988, 333-34).

To put it differently, gendered forms of discrimination "probably" exist in the Melanesian context, but they attach themselves not to stable biological categories such as "a woman" but to fluid situational contexts in which people of both sexes can be subjected to them. Feminism is an arcane Western discursive practice that is premised on the inordinately rigid and biologically inflected notion of sex and particularistic, all-too-modern version of the commodity logic.

Finally, the very notion of the person as it is understood in the West is alien to Melanesian societies. Capitalist economies produce commodities and individuals - both entities being, in effect, the reflection of each other. They are conceived as autonomous detachable units that do not bear any connection to the relationships that brought them into being. Instead, in the context of Melanesia, the dominating form of personhood is dividual: "a $\mathrm{s} / \mathrm{he}$ who is multiply authored or caused and who is complexly positioned within a network of consanguines and affines. Unlike the Western' individual', the 'dividual' is always already social: born of others and dependent and interdependent rather than autonomous" (Biersack 1991, 148). According to Strathern, "Far from being regarded as unique entities, Melanesian persons are as dividually as they are individually conceived. They contain a generalized sociality within" (Strathern 1988, 13). The project of the New Melanesian Ethnography, as it came to be popularly known in the aftermath of publication of The gender of the gift, boiled down to re-describing and re-conceptualizing the processes and phenomena of Melanesian life from the viewpoint of such a "dividual" person and the "merographic" sociality in which it was enmeshed.

\section{The limited heuristic potential of the dividual model}

The contribution made by The gender of the gift is expansive and, in the opinion of the present writer, uneven. It is a solid study of the ritual systems of Papua New Guinea that explicates the mechanics behind ceremonies and social phenomena that the discipline struggled with for some time. However, read as a manifest of the new methodological approach (either for Melanesianists or anthropology at large), it appears as both very modest in terms of the conceptual resources it offers and politically complicit with the real and pressing infrastructure of inequality that exists in PNG and elsewhere in Melanesia. The former argument will be considered in the present subsection and the latter will be discussed in the concluding one.

Before turning to the question of what the doctrine of the dividual personality can illuminate it is useful to consider is there something it cannot. Worst theories, contrary to popular opinion, are not the ones that explain nothing, but the ones that explain everything. Strathernian NME due both to her style of writing and the nature of the phenomena it posits is highly speculative even by humanities' standards. Strathern claims to illuminate the logic behind the constitution of Melanesian personhood and sociality. That way neither the absence of the concepts analogous to "dividuality" in the PNG languages nor its irreducibly unobservable character 
can be used against her. It is obviously unreasonable to apply the falsification criterion to theories in the social sciences. But they should offer at least some procedures for eliminating the hypotheses that are more wrong than others.

Case in point: the spread of Christianity in Melanesia. For decades anthropologists considered Christian Church to be one of the principal agents of modernization in Oceania and, as such, both the harbinger of and the driving force behind the transformation of local societies and, in Strathern's terms, types of personhood. The doctrine of personal salvation, the procedure of confession, and the individual relationship each convert was supposed to establish with Christian God were viewed as decidedly individualistic and foreign to Melanesian religious traditions. The contrast between Christianity and pre-Christian beliefs provided an animating force behind such works as Sabine Hess's study of the images of afterlife on Vanua Lava, Vanuatu (Hess 2006). Yet, in 2010 Mark Mosko published a paper arguing that rapid conversions to Christianity in many Melanesian societies are better understood as the result of the fundamental dividuality of Christian concepts and practices: the Eucharist, seemingly premised on indefinite expansion and division of the body of "another (albeit extraordinary) human" (Mosko 2010, 231); the omnipresence and omniscience of God; the permeability of the personages of the Holy Spirit and Jesus Christ (Mosko 2010). What are we to make of such a spectrum of possibilities? Is Christianity, after all, analogous to Melanesian personhood and therefore attained such popularity in the region or is it strictly individualistic, and bifurcated the sociality of Melanesians against the resistance of local cultures? The two cannot be right at the same time, but Strathernian methodology does not provide any measure by which one hypothesis can be considered more accurate than the other.

Secondly, several anthropologists convincingly demonstrated the existence of the phenomena that are explicitly constructed as individualistic and psychologically "inwardly oriented" by the Melanesian cultures. Edward LiPuma brought attention to the figure of the sorcerer who is defined as somebody who defies relations of reciprocity, acts of his own ill will, and is psychologically inexplicable from a dividual standpoint in a sense that the motivation for his action cannot be found in anything other people did. "[The Maring] speak first of the sorcerer as someone who wantonly disregards the limits of kinship and thus of morality. [...] Greed overcomes him, envy «eats» him, and so he turns on his own kin" (LiPuma 1998, 70). It is true that the sorcerer is a socially despised, feared, and, therefore, marginal figure. Yet, he is central to Maring and, indeed, Melanesian sociality in another respect: anybody, even the closest kinsmen can and at some point do become suspected of practicing sorcery. According to LiPuma's informants, "it is very reckless to discount the reality that someone living nearby, even though they may appear oh so normal, may be deeply engaged in sorcery. In this sense, the sorcerer as a "species" of person is an abstract personification of a set of actions and relations" (LiPuma 1998, 71). It should also be remembered that accusations of sorcery present one of the most frequently encountered types of crimes routinely investigated by custom courts and arbitrated by chiefs (see Forsyth 2009 for a variety of cases from Vanuatu).

Michele Stephen records an even more impressive instance of practices of individuality among the Mekeo of Papua New Guinea-the use of dreams as tools for psychological self-exploration. Stephen's Mekeo respondents discussed with herthough only after a protracted period of getting used to doing so - the insights they gained from analyzing the journeys of their "dream-selves." That is to say, the Mekeo believe that the acts a person's self does in his or her sleep (including his or her appearance in dreams of other individuals) reveal secret desires and urges even if they are hidden from the ego's waking consciousness (Stephen 1996). For the anthropologist, this merits analysis in terms of classical Freudism, but what should be emphasized instead is the presence of such fine-tuned and finegrained discursive practices, practices clearly oriented towards individual psychology and "inner life" among the supposedly "dividual" cultures of Papua New Guinea.

Last but not least, what exactly is gained by positing the existence of a fundamentally alien personhood unit in Melanesia that cannot be achieved by recourse to more traditional explanatory concepts? Considering how counterintuitive dividuality is, how fraught it is with a potential for othering, why should we turn to it at all if the absolute majority of the phenomena reported above can be accounted for as instances of suchadmittedly less postmodern-ish-notions as "collectivism," "peer pressure," or "the beliefs in the supernatural"? The Sia Raga belief in the reembodiment of maternal ancestors (see the second subsection of the current paper) is remarkably similar to Buddhist beliefs in reincarnation, yet we can conceptualize the existence of the latter without questioning the integrity of personhood of adherents of Buddhism. The understanding that the death of 
the PNG gang member should be reciprocated even if it is carried out by the state among Port Moresby prison inmates points to the particular local variant of lex talionis, not to the fact that Papua New Guinean criminals consider each other to be parts of the same person. The way the Maring choose to speak about the personalities of their peers is a fascinating linguistic convention but it is not necessary to believe that it reflects some ontological reality in order to study it and create satisfactory ethnographic descriptions. The concept of dividuality does too much without ever doing enough. It is too cumbersome, sensationalist, and too impractical in the field to be considered useful, let alone irreplaceable.

\section{Problems with women in Melanesia}

Strathern's lack of recognition of power inequalities has been one of the most consistent lines of critique of NME ever since the publication of The gender of the gift (Biersack 1991; Josephides 1991). In this respect, the following argument is not going to open a new avenue of discussion. However, hopefully, it will demonstrate just how grossly at odds Strathern's intellectual constructions are with the lived reality of Melanesian societies.

To reiterate, according to The gender of the gift gender relationships in Melanesia "do not entail relations of permanent domination" (Strathern 1988, 334). This conclusion in and of itself entails a massive omission of ethnographic data. In the words of Aletta Biersack, Strathern's survey

of the 'positions from which people act' [Strathern 1988, 285] excludes the public/domestic axis, which is by implication relegated to the status of an informal feature of Melanesian societies. In Melanesian the public/domestic distinction cannot be dissociated from a politics that accords the most general leadership positions to those who acquire public preeminence; these are apparently always males, not females. Men have a' general prominence in public affairs' (Strathern 1988, 34). Politics is therefore in the first instance 'sexual' (Biersack 1991, 150).

Moreover, the sociology behind The gender of the gift does not only fail to recognize persistent gender inequalities, it, to use a phrase of Lisette Josephides, "appears to discount as Western irrelevance the idea that there may be contrasting interests between the individual and the group" (Josephides 1991, 157). Strathern's agenda of "decolonizing" anthropology through taking native constructions and frames of reference as unproblematic and exempt from conflicting power relations is staggeringly sociologically naïve. Native ritual systems and symbolic doctrines are also ideological constructions aimed at naturalizing inequalities and promoting willful "misrecognition" of relations of domination and submission as relations of equality and reciprocity. Strathern falls in the very trap Michael Taussig cautioned "symbolic analysts" about in his classical monograph on the commodity fetishism in Columbia and Bolivia:

Unless we also realize that the social relations symbolized in things are themselves distorted and self-concealing ideological constructs, all we will have achieved is the substitution of a naive mechanical materialism by an equally naive objective idealism ("symbolic analysis"), which reifies symbols in place of social relations. The social relations that the analyst reads in the symbols, the collective representations, and the objects that fill our daily life are more often than not conventions about social relations and human nature that society parades as its true self (Taussig 2010, 9).

Both the dividuality of persons (i.e. their inability to properly function on their own in the absence of "guidance" from kinsmen and community-level institutions) and the supposed "reversibility" of positions of men and women is what Melanesian societies would like their members to believe about themselves in order to maintain social order. "Melanesian societies" from the previous sentence, of course, are not the totalities of individuals but the minoritarian groups that successfully retain monopoly of control over political power and discourse - chiefs, men, the elders. "Dividuality" and the supposed "symmetry of positions of action" between genders are not "controlled fictions" but controlling fictions, secreted by the traditionalist ideological hegemony - this time in cahoots with supposedly humanistic discourse of anthropology-to legitimize itself. "Domination" and "emancipation" are, without doubt, Western concepts but their rejection would not make the social sciences "objective" and "unbiased." It will merely turn them into verbose accomplices of local ideologies of submission and traditionalist elites.

In the introduction to the volume she edited, Marilyn Strathern asked the question that can pose any difficulty whatsoever only to an alien, noncarbon based form of life, and a postmodernist theorist: "To regard ourselves as dealing in inequality is to make an explicit stand in relation to 
the analytical activity which here defines us: how we make known to ourselves that inequalities exist" (Strathern, cited in Street and Copeman 2014, 7, my emphasis). There is, I would argue, a very simple way to understand if we are dealing with inequality. Let us stage a little experiment and see if the reader can spot it. I will rely on Vanuatu material, but the same demonstration can be undertaken for any region of Melanesia.

As Margaret Jolly reports, in modern Vanuatu there is a "widespread acceptance of the principle that only men can be jifs (chiefs)" (Jolly 2005, 158). She also observes, that up until 1991—a decade after Vanuatu gained independence - the fieldworkers of the Vanuatu Cultural Center were exclusively males and "indeed many considered women quite inappropriate to record or recuperate kastom - be it knowledge, myths, songs and rituals" (p. 160). According to the report compiled by the National Council of Women in Vanuatu, the gendered reality of life in the archipelago routinely includes:

The predominance of men in committees, councils and Parliament, men's higher status within the job market, higher pay and greater ease of promotion, men's greater opportunities in school and training, men's freedom to spel (take a break), to congregate with friends and tell stories in nakamals (men's houses). [The report] also bemoans that women do not bear their own names and identities but those deriving from men, that men own property and that women are the property of men, and that men enjoy freedom, while women do not (Jolly 2005, 163).

In an earlier paper, Jolly described two representative cases of kastom courts' decisions in the matters of rape (from the northern island of Ambae) and the marital dispute (from the southern island of Tanna):

[The rape case] was settled by a kastom jif through a series of compensations in the form of pigs and mats. In tracing the flow and value of these payments the Chief Justice revealed that those paying the heaviest fines were the man who had rescued [the victim] from her rapist and carried her back to her house after the rape, and the woman who was the victim of the rape. Another memorable case involved a woman from Tanna who was having matrimonial difficulties with her husband. He wanted to sort out their dispute in a kastom meeting; she refused to attend but was forced to do so. At this meeting a kastom jif declared that she must return to Tanna and she was kidnapped by eleven Tannese men and put on a boat for home (Jolly 1996, 181).
This is how Lissant Bolton, clearly influenced by the writings of Marilyn Strathern (she cites The gender of the gift as a seminal source in a later monograph), chooses to conceptualize the ethnographic reality of women not having rights to own or inherit land in Vanuatu:

Men and women practise their relation to land in its productive capacity in different ways. In east Ambae, kinship is organised through matrilineal moieties, a person's social location is inherited from their mother. Land transmission practices appear to vary from district to district, the system seems to be changing; but both men and women have a variety of rights to land accessed through male members of their clan or descent group, while men exercise greater or lesser control over the allocation of these rights according to their social position. Landholding and land transmission are predominantly male practices. Women exercise their relationship to land by bearing children to it. By bearing children to a place, a woman connects a descent group to that place (Bolton 1999, 49 , my emphasis).

Now, here is a paragraph finally purified of Western intellectual imperialism. One only wonders why stop there. It can also be said that women "exercise their relationship to education" by sending their children and male siblings to school. Or that they "exercise their relationship to power" by becoming the wives and constituents of male politicians.

Bolton also records that "women do not often speak at meetings attended by men" (Bolton 2003, 66). Taylor informs that "Men and women tend to establish separate lesser paths between hamlets, with male routes often taking a more elevated approach" (p. 136) and "the norm for women and men [is] to sit on different sides of the church" (Taylor 2008, 151). Forsyth relates that kastom courts consider women wearing trousers a crime that merits prosecution (p. 184) and that "In many communities [in Vanuatu], a woman walking alone is seen as inviting sexual attention, so there will be little sympathy for her if she finds herself in trouble as a result of this" (Forsyth 2009, 135, note 178).

Forsyth's monograph about the justice system(s) of Vanuatu has much more to tell: "sometimes women or girls are given away as part of kastom payments [...] A police officer in Tanna confirmed that a way of making peace was to give a woman to replace the life that had been taken. The practice also exists in [the islands of] Malekula and in Erromango - not just for murder but for adultery" (Forsyth 2009, 123). There is little wonder that the marriages concluded in such fashion often result in 
unhappy relationships characterized by high levels of domestic violence:

Not all youth are opposed to arranged marriages, but a significant number blame their marital troubles on the fact that they were forced to be married, and young men and women regularly run away to urban areas to escape arranged marriages. One interviewee [...] tragically stated, 'My partner and I do these [acts of physical violence] because she was never my girlfriend. My parents and families forced me to marry her. That is why our married life will always have violence. When we are ready to die, that is when the violence will end (Forsyth 2009, 17).

Such lengths in enumerating ethnographic examples and reports is taken in order to show that gender discrimination is not an afterthought or a rarity but one of the central features of the Melanesian life. Women are spatially segregated; routinely deprived of the fruits of their labor; do not own or inherit land rights; are limited in the choices of where they can go and what to wear; subjected to forced marriages and kidnappings; suffer from conjugal violence disproportionately; are rarely elected to official offices or other positions of power; are denied the right to speak; and are used as payments in settling criminal cases in kastom courts. How, indeed, can we make sure that all this amounts to relations of inequality?

The failure to notice - much less account forthe existence and scope of gender discrimination is not only a spectacular ethical defeat, but also a major theoretical weakness. To conclude this section, I will reproduce the story from the island of Ambae recounted to Lissant Bolton by a ni-Vanuatu poet and women rights activist Grace Molisa. According to the anecdote, there once was "a woman who lived as a man and became a highly successful high-ranking chief (with ten wives), but who was eventually exposed (literally) as a woman when someone glimpsed her genitals" (Bolton 2003, 60). Alas! If only those Ambaeans have read some New Melanesian Ethnography and knew that gender identity in the region is not a stable ontological category and has little to do with biological sex.

\section{Conclusions}

Despite the frequency with which Strathern's work is today cited in academic publications [... [s]ecretly, senior scholars of her own generation admit to never having read some of her most wellknown books or to finding them incomprehensible (Street and Copeman 2014, 2).

There is an entire political economy at work in promoting the writings characterized by obscure, toilsome, infinitesimally self-referential style to academic stardom. The existence of such books as The gender of the gift sustains the survival of a class of professional interpreters and exegetists that contribute to collected volumes and special editions of journals the texts that claim to explain the scriptures of the Titans. They also attain an advantage in the realm of scholarly practice in a different respect. By positing something clearly nonsensical and counterintuitive - such as the fact that the persons of Melanesians are actually divisible and not centered in their bodies - they attain leverage in the race for distinction which characterizes any field of symbolic production including, regrettably, academia. They stand so far out that become the easiest to notice.

Strathern's model of "dividuality" and the project of the New Melanesian Ethnography it gave rise to possess few epistemological advantages beyond their "deconstructivist" and "decolonizing" fleur. It introduces a highly speculative conceptual framework that does not have heuristic advantages over older, less complicated, and better empirically grounded paradigms. In addition, NME creates a dangerous precedent of anthropology that chooses the side of the traditional ideological hegemony over the side of the oppressed and refuses to subject the former to critical analysis. Consequently, the discipline does not only betray the humanizing and emancipatory project that gave birth to it but also subsumes to that peculiar sort of scholastic blindness simultaneously characterized by myopia and farsightedness; the solipsism of Narcissus and the moral numbness of the Happy Prince.

\section{References}

Biersack, Aletta. 1991. "Thinking Difference: A Review of Marilyn Strathern's 'The Gender of the Gift'." Oceania 62: 147-54

Bolton, Lissant. 1999. "Women, Place and Practice in Vanuatu: a View from Ambae." Oceania 70: 43-55.

2003. Unfolding the Moon: Enacting Women's Kastom in Vanuatu. Honolulu: University of Hawai'i Press.

Forsyth, Miranda. 2009. A bird that flies with two wings: the kastom and state justice systems in Vanuatu. Australian National University Press.
Hess, Sabine. 2006. "Strathern's Melanesian 'dividual' and the Christian 'individual': A Perspective from Vanua Lava, Vanuatu." Oceania 76: 285-96.

Hirsch, Eric. 2014. "Melanesian Ethnography and the Comparative Project of Anthropology: Reflection on Strathern's Analogical Approach." Theory, Culture \& Society 31(2/3): 39-64.

Jolly, Margaret. 1996. "Woman I kat Raet long Human Raet O No? Women's Rights, Human Rights and Domestic Violence in Vanuatu." Feminist Review 52: 169-90. 
2005. "Woman-Nation-State in Vanuatu: Women as Signs and Subjects in the Discourses of Kastom, Modernity and Christianity." In Narratives of Nation in the South Pacific, 141-73. Harwood Academic Publishers.

Josephides, Lisette. 1991. "Metaphors, Metathemes, and the Construction of Sociality: A Critique of the New Melanesian Ethnography." Man 26(1): 145-61.

Lindstrom, Lamont. 1981. "Achieving Wisdom: Knowledge and Politics On Tanna (Vanuatu).” Ph.D. Dissertation, University of California, Berkeley.

LiPuma, Edward. 1998. "Modernity and Forms of Personhood in Melanesia." In Bodies and Persons: Comparative Perspectives from Africa and Melanesia, 53-79. Cambridge: Cambridge University Press.

Mosko, Mark. 2010. "Partible penitents: dividual personhood and Christian practice in Melanesia and the West." Journal of the Royal Anthropological Institute 16(2): 215-40.

Reed, Adam. 2004. Papua New Guinea'a Last Place: Experiences of Constraint in a Postcolonial Prison. New York and Oxford: Berghahn Books.
Stephen, Michele. 1996. "Dreams and self-knowledge among the Mekeo of Papua New Guinea." Ethos 24: 465-90.

Strathern, Andrew. 1992. "Looking Backward and Forward." In Ethnographic Presents: Pioneering Anthropologists in the Papua New Guinea Highlands, 250-89. Berkeley, Los Angeles, \& Oxford: University of California.

Strathern, Marilyn. 1988. The Gender of the Gift : Problems with Women and Problems with Society in Melanesia. Berkeley, Los Angeles, London: University of California Press.

Street, Alice, and Jacob Copeman. 2014. "Social Theory after Strathern: An Introduction." Theory, Culture \& Society 31(2/3): 1-31

Taussig, Michael. 2010. The Devil and Commodity Fetishism in South America. Chapel Hill: The University of North Carolina Press.

Taylor, John Patrick. 2008. The Other Side: Ways of Being and Place in Vanuatu. Honolulu: University of Hawai'i Press.

Tsing, Anna Lowenhaupt. 2015. The Mushroom at the End of the World: On the Possibility of Life in Capitalist Ruins. Princeton and Oxford: Princeton University Press.

\section{Євгеній Осієвський}

\section{ФІКЦІї КОНТРОЛЮ: МЕТОДОЛОГІЧНІ ПАРАДОКСИ ТА ПОЛІТИЧНІ ГЛУХІ КУТИ НОВОЇ МЕЛАНЕЗІЙСЬКОЇ ЕТНОГРАФІЇ}

Статтю присвячено критиці методологічного підходу в антропології Океанії, відомого як нова меланезійська етнографія (НМЕ). Автор демонструє дисциплінарні та історичні витоки методу та наводить низку етнографічних ілюстрацій (переважно з Папуа Нової Гвінеї та Вануату), котрі вказують на точки дотику HМЕ до проблемних феноменів, засвідчених у дисциплінарному архіві меланезієзнавства. У другому підрозділі статті запропоновано розгорнутий аналіз впливової монографії «Гендер дару» британської антропологині Мерилін Стратерн, що відіграла засадничу роль у формуванні нової меланезійської етнографії та вплинула на дослідників 3 інших антропологічних субдисциплін. У статті приділено увагу як специфічним компаративістським і когнітивістським моделям, розробленим Стратерн для пояснення ритуальних та економічних практик Меланезії, так і ширшій парадигмі аналізу соціальних феноменів, що бере свій початок у «Гендері дару». Автор статті розвиває два критичних аргументи стосовно центральних положень стратерніанської антропології. По-перше, пропонована дослідницею та її послідовниками модель дивідуальної особистості має вкрай обмежений евристичний потенціал у порівнянні з більш традиційними й менш контрінтуїтивними пояснювальними схемами. По-друге, НМЕ є спекулятивною та не пропонує чітких критеріїв верифікації генерованих нею гіпотез. Врешті-решт, неспроможність стратерніанської антропології не лише пояснити, а й зафіксувати існування тривкої інфраструктури гендерної експлуатації в регіоні свідчить про соціологічну наївність підходу й створює небезпечний прецедент суспільствознавчої дисципліни, що відмовляється від критики традиційних інститутів 3 огляду на власний епістемологічний релятивізм. Стаття спирається на широкий спектр етнографічного матеріалу про традиційні та модерні, ритуальні та повсякденні, економічні та правові практики населення сучасних Вануату та Папуа Нової Гвінеї.

Ключові слова: нова меланезійська етнографія, дивід, Мерилін Стратерн, Вануату, гендерна дискримінація.

Матеріал надійшов 01.03.2021

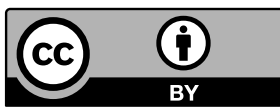

Creative Commons Attribution 4.0 International License (CC BY 4.0) 